\title{
Effects of protein and vitamin $E$ on haemoglobin formation in rats
}

\author{
By J. BUNYAN, J. GREEN AND M. A. CAWTHORNE \\ Beecham Research Laboratories, Vitamins Research Station, Walton Oaks, \\ Tadworth, Surrey
}

(Received 21 May I968-Accepted I6 June r968)

\begin{abstract}
I. Young rats were given, for 9 weeks, vitamin E-deficient diets containing either $20 \%$ or 10 \% casein, with and without a dietary supplement of $35 \circ \mathrm{ppm} \mathrm{D}-\alpha$-tocopheryl acetate. For the next 5 weeks the casein content of the low-protein diets was decreased to $7 \%$.

2. The low-protein diets induced severe growth depression.

3. The dialuric acid-induced haemolysis test showed that the rats given the $20 \%$ casein vitamin E-deficient diet were depleted of vitamin $\mathrm{E}$, but that the rate of depletion on the lowcasein diet was slower.

4. Haemoglobin levels were slightly decreased by the 10\% casein diets after 9 weeks, but this difference was not found after I4 weeks, comparing $20 \%$ and $7 \%$ casein. Dietary vitamin $\mathrm{E}$ had no effect on haemoglobin levels or erythrocyte counts.
\end{abstract}

Bencze, Gerlóczy, Ugrai \& Kneiszl (1966) recently reported that vitamin E raised the very low haemoglobin levels of rats given a vitamin E-deficient low-protein diet. The erythrocyte count of these rats was unaffected by protein depletion or vitamin $E$ deficiency or both. The vitamin E-deficient diet used by these authors contained $9 \%$ protein, consisting of casein, meat meal and yeast, all previously extracted with acetone or ether, and also an unspecified fat that had been heated to destroy vitamin $\mathrm{E}$. Although they were able to show that vitamin $\mathrm{E}$ completely prevented the anaemia they did not investigate the effect of a higher level of the extracted protein. Their $18 \%$ protein diet contained only non-extracted proteins.

In view of the importance of the connexion between vitamin $\mathrm{E}$ and blood formation and because of the uncertainties in the experimental design of Bencze et al. (1966), we have studied the effect of vitamin $E$ on haemoglobin levels in rats given various dietary concentrations of purified casein.

\section{EXPERIMENTAL}

Rats and diets. Forty-one 6-week-old Norwegian hooded rats that had previously received a vitamin E-deficient diet were allocated at random into four groups, with equal distribution of sexes and litter-mates. The groups were given, respectively, a $20 \%$ casein diet, that diet with $350 \mathrm{ppm} \mathrm{D-} \alpha$-tocopheryl acetate, a 10\% casein diet and that diet with $35 \circ \mathrm{ppm} \mathrm{D-} \alpha$-tocopheryl acetate. The $20 \%$ casein diet had the percentage composition: casein ('low vitamin content'; Genatosan Ltd) 20, salt mixture (Green, Diplock, Bunyan, McHale \& Muthy, I967) 4.93, vitamin mixture (Bunyan, Green, Diplock \& Robinson, I967) 0.4 , lard 5, sucrose 49.2 and glucose 20.47 . The 10\% casein diet had the percentage composition: casein ('low vitamin content'; Genatosan

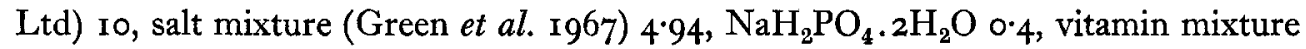


(Bunyan et al. 1967) $0^{\circ} 4$, lard 5, sucrose $59^{\circ} 2$ and glucose 20.07 . As described below, the casein content of the latter diet was decreased during the experiment to $7 \%$, with the further addition of $0.54 \% \mathrm{NaH}_{2} \mathrm{PO}_{4} \cdot 2 \mathrm{H}_{2} \mathrm{O}$ and $2 \cdot 46 \%$ glucose.

Blood tests. Blood samples were obtained from the tips of the rats' tails. Erythrocytes were counted in the usual way and haemoglobin was estimated by the cyanhaematin method of King \& Gilchrist (1947). Dialuric acid-induced haemolysis was measured as described by Bunyan, Green, Edwin \& Diplock (1960).

\section{RESULTS}

At I $_{5}$ weeks of age the haemoglobin of rats given the $10 \%$ casein diets was significantly less than that of rats given the $20 \%$ casein diets to the extent of about $0.8 \mathrm{~g} /$ roo $\mathrm{ml}$ blood (Table r). Vitamin $\mathrm{E}$ had no effect on either haemoglobin level. The rats given vitamin $\mathrm{E}$ were fully protected against dialuric acid-induced haemolysis, as expected, and those given the vitamin E-deficient $20 \%$ casein diet showed a high degree of haemolysis. However, the rats given the vitamin E-deficient 10\% casein diet did not all show haemolysis and so were apparently not all depleted of vitamin E.

For the next 5 weeks the casein content of the low-protein diet was decreased from $10 \%$ to $7 \%$ in an attempt to produce a more severe anaemia, against which vitamin $\mathrm{E}$ might have an effect. It was then found that neither vitamin $\mathrm{E}$ nor protein concentration affected haemoglobin levels and erythrocyte counts (Table I). The haemolysis test showed that the rats given the low-protein vitamin E-deficient diet were then more uniformly depleted than before, but still to a lesser extent than rats given the $20 \%$ casein vitamin E-deficient diet. As expected, the low-protein diets decreased weight gain during the experiment.

\section{DISCUSSION}

Many studies have implicated vitamin $\mathrm{E}$ in the formation of red blood cells and in their subsequent integrity and survival. Leucocytosis, anaemia and impaired erythrocyte survival have been found in vitamin E-deficient monkeys (Dinning, 1963). A vitamin E-responsive macrocytic anaemia has been found in children (Majaj, Dinning, Azzam \& Darby, 1963) and two recent reports (Binder, Herting, Hurst, Finch \& Spiro, 1965 ; Leonard \& Losowsky, 1967) have indicated diminished survival of erythrocytes in adults with vitamin $\mathbf{E}$ deficiency due to malabsorption. Vitamin $\mathbf{E}$ has also been found to increase capillary resistance in children with purpura (Gerlóczy, Lancos \& Szabo, 1966). Haemolytic anaemia occurs in premature infants with low vitamin $\mathrm{E}$ reserves (Oski \& Barness, 1967 ) and in alloxan-treated vitamin E-deficient rats (György \& Rose, I948).

Apart from the work of Bencze et al. (1966), several other reports have suggested that the action of vitamin $\mathrm{E}$ on blood formation may also be involved with the amount and nature of the dietary protein. Whitaker, Fort, Vimokesant \& Dinning (I967) found that the anaemia of Thailand children suffering from protein-calorie malnutrition was cured by a combination of vitamin $\mathrm{E}$ and protein, but not by protein alone. In the 
Vol. 22

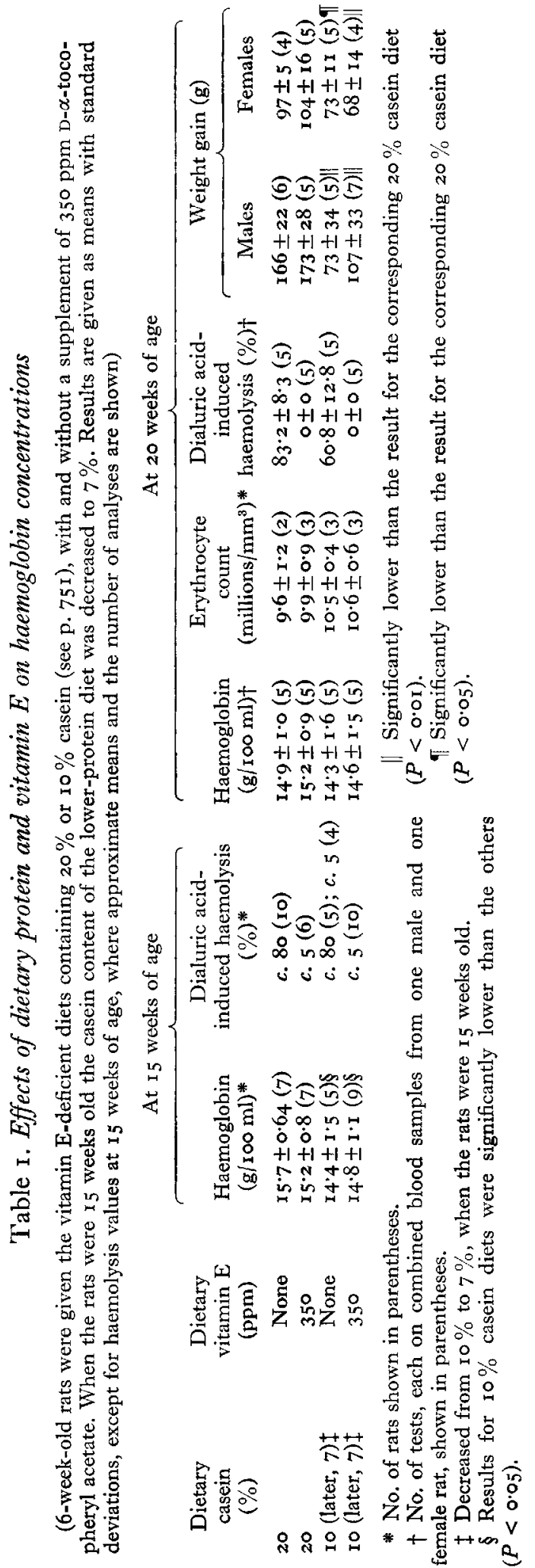


experiments of Peragello \& Fiori (1938-9), vitamin E accelerated the post-haemorrhagic regeneration of haemoglobin in dogs given a low-protein diet, but Jalavisto (I954) did not find such an effect in rabbits. Moore (I949) observed signs of anaemia in a small group of rats each given only $0.2 \mathrm{~g}$ casein and $\mathrm{I} g$ yeast per day; a test on one rat showed leucocytosis and a very low erythrocyte count, but the haemoglobin level was reported to be normal. Anaemia was not observed in the rats receiving vitamin $\mathrm{E}$ or adequate casein. More recently, Aterman \& Norkin (1963) reported lowered haemoglobin levels in rats given an (unspecified) yeast diet. Both vitamin $\mathrm{E}$ and Se prevented the liver necrosis induced by the diet, but only vitamin $\mathrm{E}$ prevented the anaemia. Lazier \& Beveridge (1964) found that the haemoglobin of rats given a torula yeast diet was depressed $12-20 \%$ below that of rats given the diet supplemented with a combination of methionine, cystine, Se and vitamin $\mathrm{E}$. Rats given supplements of either methionine or Se or vitamin $\mathrm{E}$ had 10\% less haemoglobin than fully supplemented controls. However, anaemia is not usually found in vitamin E-deficient rats given a diet of normal protein content. Thus, Dinning, Young, Simmons \& Day (1954) found no change in the erythrocyte count or haemoglobin level of rats made deficient of vitamin $\mathrm{E}$ or pyridoxine or both over a period of 15 weeks, although there was a considerable rise in the neutrophil count. Tests on 9-month-old vitamin $E$ deficient and vitamin E-supplemented rats from our own colony showed $15 \cdot 2 \pm 1 \cdot 9$ and $\mathrm{I}_{4} \cdot 2 \pm \mathrm{I} \cdot \mathrm{I} \mathrm{g}$ haemoglobin/I00 $\mathrm{ml}$ blood, respectively. Both diets contained $15 \%$ protein as casein.

We have been unable to confirm the finding by Bencze $e t$ al. (1966) of a $70 \%$ loss of haemoglobin in vitamin E-deficient rats given a low-protein diet or any effect of vitamin $\mathbf{E}$ on haemoglobin levels. We used diets containing lard and purified casein and adequate supplements of the $B$-vitamins and vitamins $A, D_{3}$ and $K$. However, haemoglobin levels were not depressed by more than $2-8 \%$, even though the rats were clearly depleted of protein, as evidenced by their poor weight gains, and of vitamin $\mathrm{E}$, as evidenced by the positive haemolysis test. The severe anaemia produced in the experiments of Benzce et al. (1966) may have been caused by several factors other than depletion of protein and vitamin $\mathbf{E}$. Toxic substances may have been produced by the solvent extraction of the protein component of the diet and also by heating the fat component. If a secondary B-vitamin deficiency was involved it is unlikely that it was pyridoxine deficiency, in the light of the work of Dinning et al. (1954) referred to earlier.

It would be of great interest to discover the true cause of the anaemia induced by Bencze et al. (1966) in view of the complete activity of vitamin $\mathrm{E}$ in preventing it.

\section{REFERENCES}

Aterman, K. \& Norkin, S. (1963). Fedn Proc. Fedn Am. Socs exp. Biol. 22, 602.

Bencze, B., Gerlóczy, F., Ugrai, E. \& Kneiszl, F. (1966). Int. Z. VitamForsch. 36, 24.

Binder, H. J., Herting, D. C., Hurst, V., Finch, S. \& Spiro, H. M. (1965). New Engl. F. Med. 273, 1289 .

Bunyan, J., Green, J., Diplock, A. T. \& Robinson, D. (1967). Br. F. Nutr. 21, I 37.

Bunyan, J., Green, J., Edwin, E. E. \& Diplock, A. T. (1960). Biochem. F. 75, 460.

Dinning, J. S. (1963). Nutr. Rev. 2r, 289.

Dinning, J. S., Young, J. M., Simmons, M. R. \& Day, P. L. (1954). Proc. Soc. exp. Biol. Med. 85, 280. 
Gerlóczy, F., Lancos, F. \& Szabo, J. (1966). Acta paediat. hung. 7, 363.

Green, J., Diplock, A. T., Bunyan, J., McHale, D. \& Muthy, I. R. (I967). Br. F. Nutr. $21,69$. György, P. \& Rose, C. S. (1948). Science, N.Y. по8, 7 16.

Jalavisto, E. (1954). Annls Med. exp. Biol. Fenn. 32, 195.

King, E. J. \& Gilchrist, M. (r947). Lancet ii, 201.

Lazier, B. B. \& Beveridge, J. M. R. (1964). Can. F. Biochem. 42, I809.

Leonard, P. J. \& Losowsky, M. S. (1967). Biochem. F. 103, 5 I P.

Majaj, A., Dinning, J. S., Azzam, S. \& Darby, W. J. (1963). Am. F. clin. Nutr. I2, 374.

Moore, T. (1949). Ann. N.Y. Acad. Sci. 52, 206.

Oski, F. A. \& Barness, L. A. (1967). F. Paediat. 7o, 2 I 1.

Peragello, I. \& Fiori, E. (1938-9). Z. VitamForsch. 8, r32.

Whitaker, J. A., Fort, E. G., Vimokesant, S. \& Dinning, J. S. (1967). Am. F. clin. Nutr. $20,783$. 